\title{
Behavior of an enterotoxigenic Staphylococcus aureus strain during manufacture of the Moroccan fermented milk "Iben"
}

\author{
A Hamama 1, SR Tatini 2 \\ 1 Département d'Hygiène et Industrie des Denrées Alimentaires d'Origine Animale (HIDAOA), \\ Institut Agronomique et Vétérinaire Hassan II, BP 6202 Rabat-Instituts, Rabat, Morocco; \\ 2 Department of Food Science and Nutrition University of Minnesota, St Paul, MN 55108, USA
}

(Received 21 January 1991; accepted 15 June 1991)

\begin{abstract}
Summary - Two lots of Moroccan lben (skimmed fermented milk) were prepared from raw milk inoculated with 2 levels of an enterotoxigenic Staphylococcus aureus strain (10 3 and $105 / \mathrm{ml}$; type C toxin) and spontaneous fermentation at room temperature $\left(24-25^{\circ} \mathrm{C}\right)$ for $72 \mathrm{~h}$. With an inoculum level of $1 \times 10^{3} / \mathrm{ml}, S$ aureus reached a maximum of 7.2 and $8.3 \times 10^{4} / \mathrm{ml}$ within $24 \mathrm{~h}$ with no accumulation of thermonuclease (TNase). With the higher initial inoculum of $1 \times 10^{5} / \mathrm{ml}, S$ aureus attained a maximum level of 1.8 and $3.4 \times 10^{7} / \mathrm{ml}$ with accumulation of detectable TNase and enterotoxin within $24 \mathrm{~h}$. S aureus level declined between 24 and $72 \mathrm{~h}$ in lben, whereas both TNase and enterotoxin $\mathrm{C}$ persisted. TNase was first detected between 8 and $12 \mathrm{~h}$ with an $S$ aureus level $\approx$ $2 \times 10^{6} / \mathrm{ml}$ and no enterotoxin C, whereas both TNase and toxin were detected later (between 12 and $24 \mathrm{~h}$ ) with an $S$ aureus level of $4.9 \times 10^{6} / \mathrm{ml}$ in one lot and $3.4 \times 10^{7} / \mathrm{ml}$ in the other. Control of initial $S$ aureus level to $10^{3} / \mathrm{ml}$ in milk and detection of TNase as a screening test for enterotoxin presence in lben should help to reduce the public health hazards of staphylococcal food poisoning.
\end{abstract}

Iben / S aureus / thermonuclease / enterotoxin

Résumé - Comportement d'une souche de Staphylococcus aureus entérotoxinogène au cours de l'élaboration du lait fermenté marocain «lben». Deux lots de lben marocain (lait fermenté écrémé) sont préparés à partir d'un lait cru inoculé avec 2 taux différents $\left(10^{3}\right.$ et $105 / \mathrm{ml}$ ) d'une souche de Staphylococcus aureus productrice d'entérotoxine C. La fermentation spontanée est conduite à température ambiante $\left(24-25^{\circ} \mathrm{C}\right.$ ) pendant $72 \mathrm{~h}$. Avec un taux initial de $1 \times 10^{3} / \mathrm{ml}$, S aureus atteint son maximum $\left(7,2\right.$ et $\left.8,3 \times 10^{4} / \mathrm{ml}\right)$ au bout de $24 \mathrm{~h}$ sans accumulation de thermonuclease (TNase) dans les 2 lots. Avec un taux initial de $1 \times 10^{5} / \mathrm{ml}$, S aureus atteint 1,8 et $3,4 \times 10^{7} / \mathrm{ml}$ après $24 \mathrm{~h}$ avec production de TNase et d'entérotoxine $C$ dans les 2 lots de lait. Entre 24 et 72 h, les taux de $\mathrm{S}$ aureus diminuent dans le lben alors que la TNase et l'entérotoxine persistent. La TNase est détectée bien avant l'entérotoxine (entre 8 et $12 \mathrm{~h}$ ) lorsque le taux de $\mathrm{S}$ aureus est voisin de 2,0 $\times 10^{6} / \mathrm{ml}$. La détection simultanée de la TNase et de l'entérotoxine est obtenue entre 12 et $24 \mathrm{~h}$ avec un taux de $S$ aureus de $4,9 \times 10^{6} / \mathrm{ml}$ dans un lot et $3,4 \times 10^{7} / \mathrm{ml}$ dans l'autre lot. L'utilisation de lait contenant moins de $10^{3} \mathrm{~S}$ aureus $/ \mathrm{ml}$ et la recherche de la TNase pour sonder la présence éventuelle d'entérotoxine dans le lben sont des mesures qui peuvent réduire les risques d'entérotoxicose staphylococcique. 


\section{INTRODUCTION}

Staphylococcus aureus may be found in raw milk originating either from cows or humans (hand milking) and these can multiply during storage, transport and processing such as in dairy products made from raw milk (Sharpe et al, 1965; Abo-Elnaga, 1972; Minor and Marth, 1972; Naguib et al, 1979; Dos Santos et al, 1981; Holmberg and Blake, 1984; Batish and Chander, 1987; Hamama, 1989). Further contamination from human sources may also occur at the processor level in dairy shops that manufacture and sell traditional Moroccan dairy products, namely lben (skimmed fermented milk), jben (traditional fresh cheese), raib (fermented milk) and farm butter (Hamama, 1989). Enterotoxigenic $S$ aureus were found in raw milk at a level of $10^{4}-10^{5} / \mathrm{ml}$ and also in traditional dairy products $\left(10^{5}-10^{6} / \mathrm{ml}\right.$ or $\left.\mathrm{g}\right)$. Although data regarding the incidence of staphylococcal intoxications from these products are not available, some of these products, particularly lben (5 market samples of 30 ) showed preformed enterotoxin C (Hamama, 1989). No other type of staphylococcal enterotoxin was found in this product. Some studies indicate that in general $S$ aureus is a poor competitor with raw milk microflora (Troller and Frazier, 1963; Radish et al, 1967; Halpin-Dohnalek and Marth, 1989) and that in high count raw milk it may grow poorly with no enterotoxin produced (Donnelly et al, 1968; Tatini et al, 1971). Moroccan raw milk used for making lben is usually of high total count $\left(10^{6}-10^{7} / \mathrm{ml}\right)$ and fermentation takes place at room temperature $\left(15-25^{\circ} \mathrm{C}\right)$ depending on the season. This may not favor growth of $S$ aureus and production of enterotoxin in such conditions. However, the behavior of $S$ aureus appears to depend upon many other factors such as the nature of the competing microflora, $S$ aureus initial level, $\mathrm{pH}$ and temperature of fermentation. Until now, no information has been available on the fate of enterotoxigenic $S$ aureus during Iben making. Therefore, the aim of this work was to study the behavior of an enterotoxigenic $S$ aureus strain with 2 initial levels during lben manufacture relative to growth and production of thermonuclease (TNase) and enterotoxin.

\section{MATERIALS AND METHODS}

\section{S aureus culture}

$S$ aureus strain L30 (API Staph System code 7740 , Analytab Products, Plainview, NY, USA) previously isolated from lben (Hamama, 1989) and which produces enterotoxin $\mathrm{C}$ was used in this study. This strain produces $11.5 \mu \mathrm{g}$ TNase/ $\mathrm{ml}$ (in brain heart infusion (BHI) broth after $24 \mathrm{~h}$ at $37^{\circ} \mathrm{C}$ ) which approximates the average level of TNase produced by enterotoxigenic strains isolated from Moroccan traditional dairy products (Hamama, 1987). A 24-h culture of this organism in BHI broth at $37^{\circ} \mathrm{C}$ was obtained and used to make different dilutions. The optical density $(O D, 600 \mathrm{~nm})$ was measured with a spectrophotometer (Spectronic 20, Bausch and Lomb, USA) in order to prepare a standard equation of the type $Y=a X+b$ where $Y$ stands for $\log S$ aureus count and $X$ for the corresponding OD. The equation obtained had the following formula: $Y=4.70 X+7.23$ and was used to make the appropriate dilutions of $S$ aureus culture to obtain the desired inocula of $1 \times 10^{3}$ and $1 \times 10^{5} \mathrm{~S}$ aureus $/ \mathrm{ml}$ of raw milk.

\section{Inoculation of raw milk}

Two lots of 9 I of raw milk were obtained from the experimental farm of the Institut Agronomique et Vétérinaire Hassan II (Moghrane, Gharb) in sterilized glass containers. Each lot was divided into 3 portions of 3 I each. Two portions were inoculated with the appropriate dilution of a 24-h culture of $S$ aureus L30 to obtain 
inoculum levels of $1 \times 10^{3}$ and $1 \times 10^{5} / \mathrm{ml}$ of raw milk. The third non inoculated portion was used as control. The inoculated and control milks were held at room temperature $\left(24-25^{\circ} \mathrm{C}\right)$ to allow spontaneous fermentation as is done by the dairy shops to make lben.

\section{Sampling and analyses}

Though coagulation of raw milk usually occurred after $48 \mathrm{~h}$ of incubation at room temperature, Iben was made from this fermented milk after an additional $24 \mathrm{~h}$ (total of $72 \mathrm{~h}$ ). Coagula were churned for 20 to $30 \mathrm{~min}$ in half-filled glass containers. A volume of approximately $10 \%$ warm sterile water was added during churning to help aggregate butter grains at the surface, which were then removed using a sterile scoop.

Samples at $0,4,8,12,24,48,72,96$ and $120 \mathrm{~h}$ following $S$ aureus inoculation were examined for $\mathrm{pH}$, total aerobic count, $S$ aureus count and presence of TNase and enterotoxin.

\section{pH measurement}

Sample $\mathrm{pH}$ was determined using a $\mathrm{pH}$ meter apparatus (E-520 Metrhom Herizan, Switzerland).

\section{Microbial counts}

Standard plate count (SPC) was obtained by pour-plating appropriate sample dilutions in plate count agar (PCA) plates and incubating for $48 \mathrm{~h}$ at $32^{\circ} \mathrm{C}$ (Messer et al, 1985).

$S$ aureus count was determined by surface plating of appropriate sample dilutions on BairdParker agar plates and incubating for $48 \mathrm{~h}$ at $37^{\circ} \mathrm{C}$ (Tatini et al, 1984).

\section{Thermonuclease testing}

Thermonuclease was extracted using a sample of $40 \mathrm{ml}$ of raw milk, coagulum or Iben adjusted to $\mathrm{pH} 4.5$ (Tatini et al, 1976) when necessary with a solution of $3 \mathrm{~N} \mathrm{HCl}$. Samples were then centrifuged at $10000 \mathrm{rpm}$ for $20 \mathrm{~min}$ using a $\mathrm{RC}-2$ Sorvall refrigerated centrifuge (Dupont Instruments, USA). According to the simplified procedure of Ibrahim (1981), the supernatant was not concentrated. The latter was heated for $60 \mathrm{~min}$ at $100^{\circ} \mathrm{C}$ (Tatini et al, 1984) to eliminate non staphylococcal TNase and allowed to cool. Twenty-five $\mu$ l of extract was used to fill a $5-\mathrm{mm}$ well cut into a Toluidine blue DNA agar plate (TB-DNA). To prevent eventual false positive reactions due to interaction of the acidic extract with the dye, another $25 \mu$ l of extract was placed in similar well cut into a DNA agar plate (without the dye). The DNA media (with and without the dye) were prepared as described by Kamman and Tatini (1977). After $4 \mathrm{~h}$ incubation at $50^{\circ} \mathrm{C}$, as recommended by lbrahim (1981), the TBDNA plates were observed for presence of a pink halo and the DNA plates for a clear halo around the wells. In the latter instance, TNase reaction was noted by flooding the DNA agar plates with $1 \mathrm{~N} \mathrm{HCl}$. Only samples showing specific and distinctive reactions (haloes extending $1 \mathrm{~mm}$ beyond the well) on both TB-DNA and DNA plates were considered positive.

\section{Staphylococcal enterotoxin detection}

The presence of staphylococcal enterotoxin C (SEC) was detected with staphylococcal enterotoxin reversed passive latex agglutination (SET. RPLA) test kit (Lot 34701-Oxoid Limited, Basingstoke, UK) for enterotoxin detection. The Oxoid kit recommended method for enterotoxin extraction based on a 1:2 dilution with saline solution and centrifugation was not followed. To avoid any dilution of toxin present, we instead used the supernatant (without prior boiling) from TNase testing as extract. The latter also had the advantage of being acid-treated.

\section{RESULTS AND DISCUSSION}

Data on the 2 lots of Iben made from raw milk inoculated with 2 initial levels of enterotoxigenic $S$ aureus strain L30 are presented in tables I and II. As can be seen from the tables, there was good fermentation in the 2 lots and the $\mathrm{pH}$ reached 4.5-4.7 after $48 \mathrm{~h}$. With $10^{3} \mathrm{~S}$ aureus inoculum in both lots of Iben, $S$ aureus reached a maximum population of 7.2 and $8.3 \times$ 
$104 / \mathrm{ml}$ and subsequently declined with no accumulation of TNase. Uninoculated milks showed no detectable $S$ aureus $(<10 / \mathrm{ml})$ throughout the experiment. None of the samples (inoculated or not with $S$ aureus) showed TNase, and therefore, were not expected to contain enterotoxin and thus were not tested for its presence.
With $105 / \mathrm{ml}$ initial inoculum, $S$ aureus attained a maximum population of 1.8 and $3.4 \times 10^{7} / \mathrm{ml}$ with the corresponding samples being positive for TNase and enterotoxin. It can also be seen from these data that TNase was detected before enterotoxin in each lot. Samples with 1.8-2.2 $\times 10^{6}$ $S$ aureus $/ \mathrm{ml}$ were positive for TNase but

Table I. Growth and TNase production by $S$ aureus during manufacture of Iben from raw milk. Croissance et production de TNase par $\mathrm{S}$ aureus au cours de la préparation du lben à partir du lait cru.

\begin{tabular}{|c|c|c|c|c|c|}
\hline \multirow{2}{*}{$\begin{array}{l}\text { Sampling } \\
\text { time } \\
\text { (h) }\end{array}$} & \multirow[t]{2}{*}{ Lot } & \multicolumn{4}{|c|}{ Milk inoculated with $1 \times 10^{3} \mathrm{~S}$ aureus $/ \mathrm{ml}$} \\
\hline & & $\mathrm{pH}$ & $\begin{array}{c}S P C \\
\left(1 \times 10^{6} / \mathrm{ml}\right)\end{array}$ & $\begin{array}{l}\text { S aureus count } \\
\left(1 \times 10^{3} / \mathrm{ml}\right)\end{array}$ & $\begin{array}{l}\text { TNase } \\
\text { reaction }\end{array}$ \\
\hline \multicolumn{6}{|l|}{ Raw milk } \\
\hline \multirow[t]{2}{*}{0} & 1 & 6.6 & 3.5 & 2.6 & - \\
\hline & 2 & 6.7 & 1.3 & 1.6 & - \\
\hline \multirow[t]{2}{*}{4} & 1 & 6.6 & 8.8 & 4.5 & - \\
\hline & 2 & 6.7 & 2.2 & 3.3 & - \\
\hline \multirow[t]{2}{*}{8} & 1 & 6.4 & 29.0 & 21.0 & - \\
\hline & 2 & 6.6 & 14.0 & 15.0 & - \\
\hline \multirow[t]{2}{*}{12} & 1 & 6.1 & 73.0 & 56.0 & - \\
\hline & 2 & 6.4 & 31.0 & 46.0 & - \\
\hline \multirow[t]{2}{*}{24} & 1 & 5.3 & 213.0 & 72.0 & - \\
\hline & 2 & 5.8 & 230.0 & 83.0 & - \\
\hline \multicolumn{6}{|l|}{ Coagulum } \\
\hline \multirow[t]{2}{*}{48} & 1 & 4.5 & 870.0 & 6.8 & - \\
\hline & 2 & 4.6 & 1600.0 & 14.0 & - \\
\hline \multicolumn{6}{|l|}{ Lben } \\
\hline \multirow[t]{2}{*}{72} & 1 & 4.4 & 1200.0 & 3.1 & - \\
\hline & 2 & 4.5 & 2800.0 & 11.0 & - \\
\hline \multirow[t]{2}{*}{96} & 1 & 4.1 & 3300.0 & $<0.03$ & - \\
\hline & 2 & 4.2 & 3600.0 & 0.1 & - \\
\hline \multirow[t]{2}{*}{120} & 1 & ND & ND & ND & - \\
\hline & 2 & 4.0 & 2300.0 & $<0.03$ & - \\
\hline
\end{tabular}

SPC: Standard plate count; ND: Not determined. 
Table II. Growth and TNase and enterotoxin production by $S$ aureus during manufacture of Iben from raw milk.

Croissance et production de la TNase et de l'entérotoxine par S aureus au cours de la préparation du Iben à partir du lait cru.

\begin{tabular}{|c|c|c|c|c|c|c|}
\hline \multirow{2}{*}{$\begin{array}{l}\text { Sampling } \\
\text { time } \\
\text { (h) }\end{array}$} & \multirow[t]{2}{*}{ Lot } & \multicolumn{5}{|c|}{ Milk inoculated with $1 \times 10^{5} \mathrm{~S}$ aureus $/ \mathrm{ml}$} \\
\hline & & $\mathrm{pH}$ & $\begin{array}{c}S P C \\
\left(1 \times 10^{6} / \mathrm{ml}\right)\end{array}$ & $\begin{array}{l}\text { S aureus count } \\
(1 \times 105 / \mathrm{ml})\end{array}$ & $\begin{array}{c}T \text { Nase } \\
\text { reaction }\end{array}$ & SEC \\
\hline \multicolumn{7}{|l|}{ Raw milk } \\
\hline \multirow[t]{2}{*}{0} & 1 & 6.6 & 3.8 & 2.2 & - & ND \\
\hline & 2 & 6.7 & 1.8 & 1.4 & - & ND \\
\hline \multirow[t]{2}{*}{4} & 1 & 6.6 & 9.3 & 3.6 & - & ND \\
\hline & 2 & 6.7 & 2.6 & 4.7 & - & ND \\
\hline \multirow{2}{*}{8} & 1 & 6.4 & 33.3 & 8.0 & - & ND \\
\hline & 2 & 6.6 & 19.0 & 18.0 & + & - \\
\hline \multirow[t]{2}{*}{12} & 1 & 6.1 & 74.0 & 22.0 & + & - \\
\hline & 2 & 6.4 & 37.0 & 49.0 & + & + \\
\hline \multirow[t]{2}{*}{24} & 1 & 5.2 & 250.0 & 340.0 & + & + \\
\hline & 2 & 5.8 & 310.0 & 176.0 & + & + \\
\hline \multicolumn{7}{|l|}{ Coagulum } \\
\hline \multirow[t]{2}{*}{48} & 1 & 4.5 & 900.0 & 120.0 & + & + \\
\hline & 2 & 4.7 & 2200.0 & 84.0 & + & + \\
\hline \multicolumn{7}{|l|}{ Lben } \\
\hline \multirow[t]{2}{*}{72} & 1 & 4.4 & 1600.0 & 98.0 & + & + \\
\hline & 2 & 4.6 & 3400.0 & 61.0 & + & + \\
\hline \multirow[t]{2}{*}{96} & 1 & 4.0 & 3400.0 & 0.02 & + & + \\
\hline & 2 & 4.2 & 3900.0 & 0.08 & + & + \\
\hline \multirow[t]{2}{*}{120} & 1 & 3.8 & 2700.0 & $<0.0003$ & + & + \\
\hline & 2 & 4.0 & 2600.0 & $<0.0003$ & + & + \\
\hline
\end{tabular}

SPC: Standard plate count; SEC: staphylococcal enterotoxin C (RPLA test); ND: not determined.

not for enterotoxin, while those at higher levels of $S$ aureus $\left(4.9 \times 10^{6}\right.$ to $3.4 \times 10^{7}$ / $\mathrm{ml}$ ) were positive for both TNase and enterotoxin $\mathrm{C}$. These data indicate that high initial levels of $S$ aureus $(105 / \mathrm{ml})$ in raw milk can reach toxigenic levels in lben made even when the total aerobic count of raw milk was high $\left(5 \times 10^{6}-7.5 \times 10^{7} / \mathrm{ml}\right)$. This is in contrast to the studies of Donnelly et al (1968) and Tatini et al (1971) who reported lack of $S$ aureus growth and/or production of enterotoxin $A$ in high count 
raw milk. However, this difference may be due to the nature of the microflora present in the raw milks used. In our study, the initial flora was mesophilic while in the previous works cited, it was predominantly psychrotrophic.

The data obtained in this study confirm the earlier reports of others who noted $S$ aureus levels of $\geq 106 / \mathrm{ml}$ for detection of TNase (Tatini, 1981) and higher levels of $10^{7} / \mathrm{ml}$ for enterotoxin detection (Donnelly et al, 1968; Tatini et al, 1971, 1976) with the exception that in the present experiment TNase was detected even without concentrating the supernatant; this was compensated by the use of an increased test sample size $(25 \mu \mathrm{l}$ in this study instead of $5 \mu \mathrm{l}$ for the method with concentration). The method used in this study for extraction and detection of TNase from milk and Iben and which is a compilation of several previous procedures (Tatini et al, 1976, 1984; Ibrahim, 1981) was already used to screen the presence of enterotoxin in raw milk and traditional Moroccan dairy products (Hamama, 1989). This method was found to be sufficiently sensitive to de-

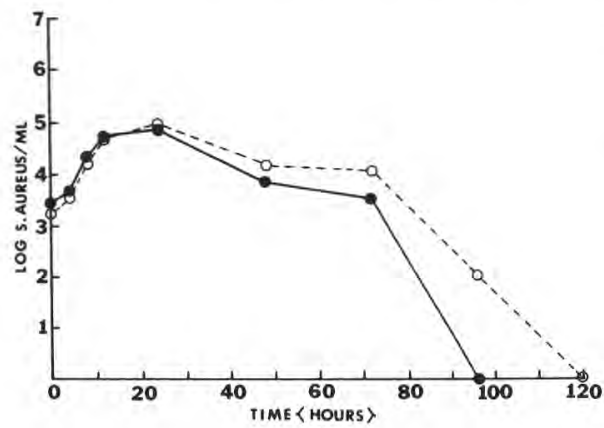

Fig 1. Growth of $S$ aureus in raw milk during Iben making (inoculum level : 1 x 103/ml) $(\longrightarrow$ Lot 1, O- - O Lot 2).

Croissance de $\mathrm{S}$ aureus dans le lait cru au cours de la préparation du lben (taux d'inoculation : $\left.1 \times 10^{3} / \mathrm{ml}\right)(\bullet$ Lot $1,0--O$ Lot 2$)$. tect TNase prior to accumulation of enterotoxin amounts detectable by the RPLA kit.

Data presented here indicate that raw milk containing high enterotoxigenic $S$ aureus count $\left(10^{5} / \mathrm{ml}\right)$ can result in enterotoxin in Iben made with spontaneous fermentation, and such growth can be detected by TNase before the development of enterotoxin C. Several other studies have been conducted in the past on the behavior of $S$ aureus in different types of dairy products (Miller and Ledford, 1977; Dos Santos and Genigecrgis, 1981; Ahmed et al, 1983; Otero et al, 1988). These studies reported contradictory results regarding the minimal levels of $S$ aureus needed before accumulation of detectable amounts of TNase. Tatini et al (1976) noted detectable levels of TNase in milk and whey when the $S$ aureus count was $5 \times 10^{5} / \mathrm{ml}$ and enterotoxin when the latter reached $5 \times 10^{6}-1 \times 10^{7 /}$ $\mathrm{ml}$, while Miller and Ledford (1977) detected TNase in Cheddar cheese whey but not enterotoxin at $1.7 \times 10^{7} \mathrm{~S}$ aureus $/ \mathrm{ml}$. When examining potential growth of staphylococ-

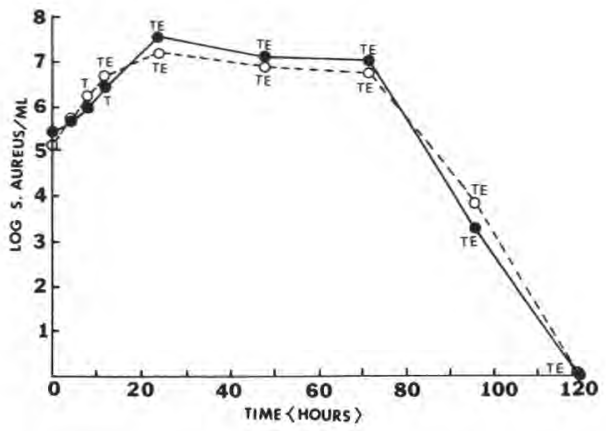

Fig 2. Growth of $S$ aureus in raw milk during lben making (inoculum level : $1 \times 105 / \mathrm{ml})(-$ Lot 1, O- - O Lot 2, T : TNase presence; TE : TNase and enterotoxin presence).

Croissance de $\mathrm{S}$ aureus dans le lait cru au cours de la préparation du lben (taux d'inoculation : $1 \times 105 / \mathrm{ml})(\longrightarrow$ Lot $1,0-0$ Lot 2, $T$ : présence de TNase; TE : présence de TNase et d'entérotoxine). 
ci in Brazilian Minase cheese whey, Dos Santos and Genigeorgis (1981) detected TNase only in samples exceeding $10^{7} / \mathrm{ml} \mathrm{S}$ aureus count. In Domiati cheese whey, Ahmed et al (1983) detected TNase and enterotoxin $A$ when the number of $S$ aureus was $1.6 \times 10^{8} / \mathrm{ml}$. Otero et al (1988) studied the behavior of $2 S$ aureus strains producing enterotoxin $C$ during the manufacture and storage of Burgos cheese. They found that the TNase test is of a limited value in assessing staphylococcal growth in this type of cheese. With $S$ aureus FRI 361 strain (low TNase producer: $0.8 \mu \mathrm{l} / \mathrm{ml}$ ), this organism reached $10^{7} / \mathrm{g}$ of cheese without amounts of detectable TNase while with strain FRI 137 (high TNase producer: $20.91 \mu \mathrm{g} / \mathrm{ml}$ ), TNase was detected when $S$ aureus attained $6.7 \times$ $10 \% / \mathrm{g}$.

It seems then that the production of TNase is mainly related to the nature of the $S$ aureus strain (low, average or high TNase producer) and to the different factors influencing $S$ aureus growth (temperature and $\mathrm{pH}$ of the substrate, initial level of $S$ aureus, type and level of competing flo$\mathrm{ra}$, etc). Therefore, the TNase testing might not have the same usefulness in all food products and under all conditions. The findings reported in this study are then valuable only for this type of fermented milk and for the particular $S$ aureus strain used in this experiment although the origin of lben and its particularities (production of SEC and average level of TNase) make it suitable enough to assess the behavior of enterotoxigenic $S$ aureus in Iben.

Data of this experiment showed that initial levels of $S$ aureus $\leq 10^{3} / \mathrm{ml}$ are not expected to result in enterotoxin $\mathrm{C}$ in lben. Subsequently, measures such as control of staphylococcal mastitis in cows and of human contamination during milking are essential to reduce enterotoxigenic $S$ aureus to $\leq 10^{3} / \mathrm{ml}$ in raw milk. However, such measures may not be easy to apply at the present time in Morocco. Since both raw milk and lben showed presence of enterotoxigenic $S$ aureus and also enterotoxin $C$ at levels that can cause food intoxication in Iben made from raw milk (Hamama, 1989), it is essential to favor a very active fermentation of raw milk so that its $\mathrm{pH}$ decreases rapidly to $<5.5$ before $S$ aureus attains hazardous levels $(>106 / \mathrm{ml}$ ) even when the $S$ aureus initial count is $105 / \mathrm{ml}$. Probably, addition of $2-3 \%$ of good quality lben to raw milk as a first step in lben manufacture may help in the control of excessive $S$ aureus growth. This alternative deserves to be experimented with in future.

With respect to the TNase test, data presented here suggest that this rapid test should be considered as a valuable tool in screening lben for staphylococcal enterotoxin.

\section{ACKNOWLEDGMENT}

This research was supported by the United States Agency for International Development.

\section{REFERENCES}

Abo-Elnaga IG (1972) Staphylokokkenvermehrung in gesalzener Rohmilch für die Herstellung von Salzlakenweisskäse. Milchwissenschaft 27, 583-586

Ahmed AAH, Moustafa MK, Marth EH (1983) Growth and enterotoxin production by Staphylococcus aureus in whey from the manufacture of Domiati cheese. J Food Prot 46, 235-237

Batish VK, Chander H (1987) Occurrence of Staphylococcus aureus and their preformed enterotoxins in frozen dairy desserts. Aust $J$ Dairy Technol 42, 22-24

Donnelly CB, Leslie JE, Black LA (1968) Production of enterotoxin A in milk. Appl Microbiol 16, 917-924 
Dos Santos EC, Genigeorgis C (1981) Potential for presence and growth of staphylococci in Brazilian Minas cheese whey. I Food Prot 44, 185-188

Dos Santos EC, Genigeorgis C, Farver TB (1981) Prevalence of Staphylococcus aureus in raw and pasteurized milk used for commercial manufacturing of Brazilian Minas cheese. J Food Prot 44, 172-176

Halpin-Dohnalek MI, Marth EH (1989) Staphylococcus aureus: production of extracellular compounds and behavior in foods. A review. $J$ Food Prot 52, 267-282

Hamama A (1987) Thermonuclease and enterotoxin and biotyping of staphylococci isolated from Moroccan dairy products. Lait 67, 403411

Hamama A (1989) Studies on the hygienic quality of Moroccan traditional dairy products. PhD Thesis, Univ Minnesota, St Paul, MN, USA

Holmberg SD, Blake PA (1984) Staphylococcal food poisoning in the United States. New facts and old misconceptions. J Am Med As$\operatorname{soc} 251$, 487-489

Ibrahim GF (1981) A simple sensitive method for determining staphylococcal thermonuclease in cheese. J Appl Bacterio/ 51, 307-312

Kamman JF, Tatini SR (1977) Optimal conditions for assay of staphylococcal nuclease. J Food Sci 42, 421-424

Messer JW, Behney HM, Leudecke LO (1985) Microbiological count methods. In: The Standard Methods for the Examinations of Dairy Products (Richardson GH, ed) Am Publ Health Assoc Washington, DC, 15th edn, ch 6, 327-404

Miller JS, Ledford RA (1977) Growth inhibition of Staphylococcus aureus in Cheddar cheese whey. J Dairy Sci 60, 1689-1692

Minor TE, Marth EH (1972) Staphylococcus aureus and staphylococcal food intoxication. A review. III: Staphylococci in dairy foods. J Milk Food Technol 35, 77-82

Naguib MM, Nour MA, Noaman AA (1979) Survival of Staphylococcus aureus in Ras cheese. Arch Lebensmittelhyg 30, 227-228

Otero A, Garcia MC, Garcia ML, Prieto M, Moreno B (1988) Behaviour of Staphylococcus aureus strains, producers of enterotoxins $\mathrm{C} 1$ or $\mathrm{C} 2$, during the manufacture and storage of Burgos cheese. J Appl Bacteriol 64, 117-122

Radish R, Sandine WE, Elliker PR (1967) Inhibition of Staphylococcus aureus by Streptococcus diacetylactis in milk and cream fillings. J Dairy Sci 52, 880 (Abstr)

Sharpe ME, Fewins BG, Reiter B, Cuthbert WA (1965) A survey of the incidence of coagulase-positive staphylococci in market milk and cheese in England and Wales. J Dairy Res 32, 187-192

Tatini SR (1981) Thermonuclease as an indicator of staphylococcal enterotoxins in foods. In: Antinutrients and Natural Toxicants in Foods (Ory RL, ed) Food and Nutrition Press, Wesport, CT, 53-75

Tatini SR, Jezeski JJ, Olson JC, Casman EP (1971) Factors influencing the production of staphylococcal enterotoxin A in milk. J Dairy Sci $54,312-320$

Tatini SR, Cords BR, Gramoli J (1976) Screening for staphylococcal enterotoxin in food. Food Technol 40, 64-76

Tatini SR, Hoover DG, Lachica RVF (1984) Methods for the isolation and enumeration of Staphylococcus aureus. In: The Compendium of Methods for the Microbiological Examination of Foods (Speck ML, ed) Am Publ Health Assoc, Washington, DC, 411-427

Troller JA, Frazier WC (1963) Repression of Staphylococcus aureus by food bacteria. I: Effect of environmental factors on inhibition. Appl Microbiol 11, 11-14 